\title{
Changes in Soil Biochemical Properties in a Cedar Plantation Invaded by Moso Bamboo
}

\author{
Yo-Jin Shiau (1) and Chih-Yu Chiu * \\ Biodiversity Research Center, Academia Sinica, Nangang, Taipei 11529, Taiwan; yshiau@ncsu.edu \\ * Correspondence: bochiu@sinica.edu.tw; Tel.: +886-2-2787-1180
}

Academic Editors: Alessandra Lagomarsino, Roberta Pastorelli and Alberto Agnelli

Received: 19 May 2017; Accepted: 21 June 2017; Published: 23 June 2017

\begin{abstract}
Moso bamboo (Phyllostachys edulis) is one of the widely growing bamboo species in Asia. Because of its fast growth and aggressive rhizomes, it is reported to invade other forests and reduce the biodiversity of forest ecosystems. To determine the changes in soil nutrient conditions due to moso bamboo invasion, this research measured the difference in soil labile carbon (C) and nitrogen (N) contents in a Japanese cedar (Cryptomeria japonica) forest invaded by moso bamboo in central Taiwan. The content of soluble organic $\mathrm{C}\left(\mathrm{S}_{\mathrm{b}} \mathrm{OC}\right)$, measured by both $\mathrm{KCl}$ and hot-water extraction methods, was lower in bamboo than cedar soils. This observation agreed with the finding that the more easily decomposed $S_{b} \mathrm{OC}$ could be lost with bamboo invasion. In addition, both $\mathrm{S}_{\mathrm{b}} \mathrm{OC}_{\mathrm{KCl}}$ and $\mathrm{S}_{\mathrm{b}} \mathrm{OC}_{\mathrm{HW}}$ contents were positively correlated with microbial biomass $\mathrm{C}$ content, so the decreased labile organic $\mathrm{C}$ content in bamboo soils may reduce microbial biomass production. Principal component analysis revealed soil organic $C$ content (total organic $C, S_{b} O C$ and acid-hydrolysable $C$ ) as the most important soil parameter affected by the bamboo invasion, followed by microbial biomass $\mathrm{N}$ and $\mathrm{NO}_{3}{ }^{-}$contents in soils. The soil quality index model also agreed with the degraded soil quality with bamboo invasion. In conclusion, the invasion of moso bamboo reduced the $\mathrm{C}$ and $\mathrm{N}$ pools in bamboo soil and degraded the overall soil quality.
\end{abstract}

Keywords: moso bamboo; invasion; soil nutrients; microbial biomass; $\mathrm{KCl}$ extraction; hot-water extraction

\section{Introduction}

Bamboo forest occupies more than 10 million hectares in the world, and $80 \%$ of the forests are located in tropical and subtropical Asia [1]. Bamboo is an important woody grass that provides various ecosystem services such as carbon (C) sequestration [2], biofuel production [3], furniture materials [4] and food for animals [5,6]. Bamboo grows quickly and can increase its height up to a rate of $17 \mathrm{~cm} \cdot$ day $^{-1}$ [7]. Because bamboo provides fast and easily decomposed C sources to soil, it provides good plantation material for ameliorating badland soils that originally contained poor organic matter and poor physicochemical properties [8].

Moso bamboo (Phyllostachys edulis) is one of the commonly growing bamboo species in Asia. However, because of its high growth rate, moso bamboo can expand rapidly and replace surrounding forests via its aggressive rhizomes $[9,10]$. Moreover, the fast-growing shoots of moso bamboo can reach their full height and occupy the canopy within 2 to 3 months [11]. Additionally, the allelopathic compounds produced by moso bamboo may suppress the growth of understory or eliminate neighboring plants [12]. Previous research has reported the impact of bamboo invasion on ecosystem functioning, such as changing plant diversity [13,14], altering soil water content [9], decreasing soil trace elements [15], and changing microbial diversity $[7,16,17]$. In addition, composition of soil total organic C (TOC) may degrade with bamboo invasion [18]. Wang et al. [18] also found that 
frequent human disturbance in bamboo plantations further induces decomposition of soil organic matter and results in bamboo soil with high humification.

Because moso bamboo litter contains more easily decomposable substances than other coniferous forests [18], the soil quality and fertility may degrade after the invasion of moso bamboo. However, the direct evidence of changing soil labile $\mathrm{C}$ and $\mathrm{N}$ content due to moso bamboo invasion has been seldom addressed. Information on these soil labile $\mathrm{C}$ and $\mathrm{N}$ stocks can be beneficial to better understand the change of ecosystem functioning before and after bamboo invasion.

Potassium chloride $(\mathrm{KCl})$ and hot-water extraction methods are successful analytical methods to determine soil conditions with vegetation changes [19-21]. The $\mathrm{KCl}$ extraction method can evaluate labile nitrogen $(\mathrm{N})$ content in soil because much of the $\mathrm{N}$ is adsorbed by soil particles (i.e., $\mathrm{NH}_{4}{ }^{+}$and soluble organic $\mathrm{N}\left(\mathrm{S}_{\mathrm{b}} \mathrm{ON}\right)$ ) and can be extracted by ion exchange of $\mathrm{K}^{+}$[22]. However, soluble organic $\mathrm{C}\left(\mathrm{S}_{\mathrm{b}} \mathrm{OC}\right)$ is more soluble in hot than cold water [21] and its content was found highly correlated with microbial biomass $\mathrm{C}\left(\mathrm{C}_{\mathrm{mic}}\right)$ and soil TOC content [20].

To provide a better understanding of how moso bamboo migrates and invades forest ecosystems and how the soil quality is altered with bamboo invasion, we measured soil labile $\mathrm{C}$ and $\mathrm{N}$ content with different extraction methods from the soil where moso bamboo has invaded Japanese cedar forests. We hypothesized that with bamboo invasion and harvesting disturbance, soil $\mathrm{C}$ and $\mathrm{N}$ contents would significantly decrease because bamboo provides mostly labile $\mathrm{C}$ and $\mathrm{N}$.

\section{Materials and Methods}

\subsection{Site and Soil Sampling}

This study was carried out in Shanlinshi, Nantou County, Taiwan $\left(120^{\circ} 46^{\prime} \mathrm{E}, 23^{\circ} 40^{\prime} \mathrm{N}\right)$, with an average altitude of $1350 \mathrm{~m}$ and annual temperature of $17^{\circ} \mathrm{C}$. Japanese cedar (Cryptomeria japonica) was reforested in some of the area in the 1970s, and moso bamboo was planted in an adjacent area at a similar time [17]. A 30- to 50-m wide transition area with both Japanese cedar and moso bamboo plants is formed currently. Details of the study site were described elsewhere [16-18]. Briefly, soil at the study site was classified as Dystrudept and the texture was moderately well drained clayey loam [23].

Soil samples were collected from six parallel transects, $50 \mathrm{~m}$ apart, that covered three vegetation covers (moso bamboo, transition and Japanese cedar), for a total of 18 plots, in February 2011. A composited soil sample of 12 soil cores (in each sampling plot) was collected in each transect by using a soil auger $(8 \mathrm{~cm}$ in diameter and $10 \mathrm{~cm}$ in depth) and stored in a plastic bag. The samples were stored at $4{ }^{\circ} \mathrm{C}$ in their initial moisture conditions before experiments.

\subsection{Laboratory Analysis}

\subsubsection{Soil General Property}

Soil TOC and total nitrogen (TN) contents were analyzed by the combustion method with a Fisons NA1500 elemental analyzer (ThermoQuest Italia, Milan, Italy).

\subsubsection{Soil Extractable Nutrients}

The $\mathrm{KCl}$ and hot-water extraction methods were used to extract soil nutrients for $\mathrm{NH}_{4}{ }^{+}, \mathrm{NO}_{3}{ }^{-}$, $\mathrm{S}_{\mathrm{b}} \mathrm{ON}$, and $\mathrm{S}_{\mathrm{b}} \mathrm{OC}$ measurement. For the $\mathrm{KCl}$ extraction, $5 \mathrm{~g}$ air-dried soil was weighed from each composited sample, placed in a 250-mL conical flask, and injected with $50 \mathrm{~mL}$ of $2 \mathrm{M} \mathrm{KCl}$. The flask was sealed with plastic paraffin film and shaken to form a slurry for $60 \mathrm{~min}$ at $150 \mathrm{rpm}$. Water was then filtered out from the slurry to test the nutrient contents. Analyses were duplicated for each soil sample collected in the field.

For the hot-water extraction, $6 \mathrm{~g}$ of air-dried soil samples was weighed from each composited sample, placed in a 50-mL centrifuge bottle and injected with $30 \mathrm{~mL}$ distilled deionized water. The bottle was placed in $70{ }^{\circ} \mathrm{C}$ water and incubated for $18 \mathrm{~h}$. The bottle was then shaken for $5 \mathrm{~min}$ at 
$150 \mathrm{rpm}$. All of the shaken bottles were centrifuged at 10,000 $\mathrm{m} \mathrm{s}^{-2}$ for $10 \mathrm{~min}$, and water from the slurry was filtered for analysis.

Soil total dissolved $\mathrm{N}$ (TDN) was digested to $\mathrm{NO}_{3}{ }^{-}$by using a persulfate method [24], then analyzed with a flow injection analyzer (SP-8001, Metertech Inc., Taipei, Taiwan). $\mathrm{NH}_{4}{ }^{+}$was analyzed by an indophenol method with a spectrophotometer (UV-1201, Shimadzu Corp., Kyoto, Japan). $\mathrm{NO}_{3}{ }^{-}$content was analyzed with a flow injection analyzer. $\mathrm{S}_{\mathrm{b}} \mathrm{ON}$ content was calculated by subtracting $\mathrm{NO}_{3}{ }^{-}$and $\mathrm{NH}_{4}{ }^{+}$from TDN content. $\mathrm{S}_{\mathrm{b}} \mathrm{OC}$ content was measured with a TOC analyzer (1010, O.I. Analytical, College Station, TX, USA).

\subsubsection{Total Mineralizable N}

Total mineralizable $\mathrm{N}$ was determined by using the waterlogging incubation method [25]. Five grams of fresh soil was placed in a 250-mL centrifuge bottle with $25 \mathrm{~mL}$ of distilled deionized water and incubated in an incubator (LM-509RD, Yihder Technology Co., Shinbei City, Taiwan) at $40{ }^{\circ} \mathrm{C}$ and $150 \mathrm{rpm}$ for 7 days. After incubation, $25 \mathrm{~mL}$ of $4 \mathrm{M} \mathrm{KCl}$ was injected into the centrifuge bottle and shaken for $1 \mathrm{~h}$ at $150 \mathrm{rpm}$. Then, the bottle was centrifuged at $2000 \mathrm{rpm}$ for $20 \mathrm{~min}$ and $50 \mathrm{~mL}$ water was extracted and filtered for determining $\mathrm{NH}_{4}{ }^{+}$concentration.

Soil water content was measured from the weight loss of soil after it was oven-dried at $105^{\circ} \mathrm{C}$ for $24 \mathrm{~h}$. All analyses were performed in duplicate. All results were converted to measures of dry weight.

\subsection{Statistical Analysis}

The significance of differences in soil nutrient content among the three vegetation types was tested by a one-way analysis of variance (ANOVA). When one-way ANOVA revealed interactions of soil physicochemical properties among vegetation, Tukey's honestly significant difference (HSD) test was applied to further test the means of all pairs of dependent variables. Relations between two soil properties were analyzed by bivariate regression analysis.

By principal component analysis (PCA), we analyzed the most critical changes of soil properties affected by bamboo invasion in the studied area. In addition, a statistics-based model based on PCA is one of the recommended methods to calculate soil quality index (SQI) with changing land uses and plantations [26,27]. Here, we also reproduced the statistics-based model based on Lu et al. [26] and Mukherjee and Lal [27] to calculate the SQI for the three different plant covers in this study. Only PCs with eigenvalues $>1.0$ were retained for calculating SQI. Soil parameters, $\mathrm{NH}_{4}^{+}, \mathrm{NO}_{3}{ }^{-}, \mathrm{S}_{\mathrm{b}} \mathrm{ON}, \mathrm{S}_{\mathrm{b}} \mathrm{OC}$, total mineralizable N, TOC, TN, $\mathrm{C}_{\text {mic }}$ and $\mathrm{N}_{\text {mic }}$ from Chang and Chiu [16], acid-hydrolysable $\mathrm{C}$ (pool I: AHPI-C; pool II: AHPII-C), and recalcitrant C (RP-C) from Wang et al. [18] were used for the PCA analysis and SQI calculation.

Statistical analysis involved use of JMP, Version Pro 10 (SAS Institute, Cary, NC, USA). Level of significance was set at 0.05 .

\section{Results}

With both $\mathrm{KCl}$ and hot-water extracts, the $\mathrm{S}_{\mathrm{b}} \mathrm{OC}$ content was significantly higher in the cedar than the transition and bamboo plantation soils (Tables 1 and 2). The $\mathrm{S}_{\mathrm{b}} \mathrm{OC}_{\mathrm{KCl}}$ content was nearly 2.5 times higher in the cedar than bamboo soils and the $\mathrm{S}_{\mathrm{b}} \mathrm{OC}_{\mathrm{HW}}$ content was more than 3.5 times higher in the cedar than bamboo soils. In addition, the $\mathrm{S}_{\mathrm{b}} \mathrm{OC}_{\mathrm{HW}}$ content was more than four times higher than the $\mathrm{S}_{\mathrm{b}} \mathrm{OC}_{\mathrm{KCl}}$ content in all locations.

Similarly, both the soil $\mathrm{NH}_{4}{ }^{+}$and TDN content was higher in cedar than transition and bamboo plantation soils with both $\mathrm{KCl}$ and hot-water extracts. In addition, $\mathrm{NH}_{4}{ }^{+} \mathrm{HW}$ content was higher than $\mathrm{NH}_{4}{ }^{+} \mathrm{KCl}$ content at all locations. Soil $\mathrm{S}_{\mathrm{b}} \mathrm{ON}_{\mathrm{KCl}}$ content was higher than $\mathrm{S}_{\mathrm{b}} \mathrm{ON}_{\mathrm{HW}}$ content in the three vegetation types. 
Table 1. Concentrations of soil soluble $\mathrm{N}$ and soluble organic $\mathrm{C}$ content in $2 \mathrm{M} \mathrm{KCl}$ extracts and $\mathrm{S}_{\mathrm{b}} \mathrm{ON} / \mathrm{TN}$ and $\mathrm{S}_{\mathrm{b}} \mathrm{OC} / \mathrm{TOC}$ ratios in the top $10 \mathrm{~cm}$ of soil in the cedar plantation, transition, and moso bamboo plantation in Central Taiwan.

\begin{tabular}{|c|c|c|c|c|c|c|c|c|c|}
\hline Vegetation & $\begin{array}{l}\mathrm{S}_{\mathrm{b}} \mathrm{OC}_{\mathrm{KCl}} \\
(\mu \mathrm{g} / \mathrm{g} \text { soil })\end{array}$ & $\begin{array}{l}\mathrm{NH}_{4}{ }^{+} \mathrm{KCl} \\
(\mu \mathrm{g} / \mathrm{g} \text { soil) }\end{array}$ & $\begin{array}{l}\mathrm{NO}_{3}{ }^{-} \mathrm{KCl} \\
(\mu \mathrm{g} / \mathrm{g} \text { soil) }\end{array}$ & $\begin{array}{l}\mathrm{S}_{\mathrm{b}} \mathrm{ON}_{\mathrm{KCl}} \\
(\mu \mathrm{g} / \mathrm{g} \text { soil })\end{array}$ & $\begin{array}{c}\mathrm{TDN}_{\mathrm{KCl}} \\
(\mu \mathrm{g} / \mathrm{g} \text { soil })\end{array}$ & $\begin{array}{c}\text { TOC } \\
(\%)\end{array}$ & $\begin{array}{l}\text { TN } \\
(\%)\end{array}$ & $\begin{array}{c}\mathrm{S}_{\mathrm{b}} \mathrm{OC}_{\mathrm{KCl}} / \mathrm{TOC} \\
(\%)\end{array}$ & $\underset{(\%)}{\mathrm{S}_{\mathrm{b}} \mathrm{ON}_{\mathrm{KCl}} / \mathrm{TN}}$ \\
\hline Cedar & $1315.3 \mathrm{a}$ & $74.3 \mathrm{a}$ & $58.1 \mathrm{a}$ & $196.3 \mathrm{a}$ & $328.7 \mathrm{a}$ & $21.46 \mathrm{a}$ & $1.33 \mathrm{a}$ & $0.60 \mathrm{a}$ & $1.46 \mathrm{~b}$ \\
\hline Transition & $455.9 \mathrm{~b}$ & $42.6 \mathrm{~b}$ & $48.2 \mathrm{a}$ & $105.6 \mathrm{~b}$ & $196.4 \mathrm{~b}$ & $7.54 \mathrm{~b}$ & $0.67 b$ & $0.58 \mathrm{a}$ & $1.51 \mathrm{~b}$ \\
\hline Bamboo & $552.2 \mathrm{~b}$ & $37.4 \mathrm{~b}$ & $39.8 \mathrm{a}$ & $130.8 \mathrm{ab}$ & $208.1 \mathrm{~b}$ & $8.00 \mathrm{~b}$ & $0.67 \mathrm{~b}$ & $0.69 \mathrm{a}$ & $1.96 \mathrm{a}$ \\
\hline
\end{tabular}

Soil soluble organic carbon $\left(\mathrm{S}_{\mathrm{b}} \mathrm{OC}\right)$; ammonium $\left(\mathrm{NH}_{4}{ }^{+}\right)$; nitrate $\left(\mathrm{NO}_{3}{ }^{-}\right)$; soil soluble organic nitrogen $\left(\mathrm{S}_{\mathrm{b}} \mathrm{ON}\right)$; total dissolved nitrogen (TDN); total organic carbon (TOC); total nitrogen (TN). Values with the same letters are not significantly different at $p=0.05$ by Tukey's honestly significant difference (HSD) test.

Table 2. Soil soluble $\mathrm{N}$ and soluble organic $\mathrm{C}$ content in hot-water extracts and mineralizable $\mathrm{N}$ and $\mathrm{S}_{\mathrm{b}} \mathrm{ON} / \mathrm{TN}$ and $\mathrm{S}_{\mathrm{b}} \mathrm{OC} / \mathrm{TOC}$ ratios in the top $10 \mathrm{~cm}$ of soil in the cedar plantation, transition, and moso bamboo plantation in Central Taiwan.

\begin{tabular}{|c|c|c|c|c|c|c|c|c|}
\hline Vegetation & $\begin{array}{l}\mathrm{S}_{\mathrm{b}} \mathrm{OC}_{\mathrm{HW}} \\
(\mu \mathrm{g} / \mathrm{g} \text { soil })\end{array}$ & $\begin{array}{l}\mathrm{NH}_{4}^{+} \mathrm{HW} \\
(\mu \mathrm{g} / \mathrm{g} \text { soil })\end{array}$ & $\begin{array}{l}\mathrm{NO}_{3}{ }^{-} \mathrm{HW} \\
(\mu \mathrm{g} / \mathrm{g} \text { soil) }\end{array}$ & $\begin{array}{l}\mathrm{S}_{\mathrm{b}} \mathrm{ON}_{\mathrm{HW}} \\
(\mu \mathrm{g} / \mathrm{g} \text { soil })\end{array}$ & $\begin{array}{l}\mathrm{TDN}_{\mathrm{HW}} \\
(\mu \mathrm{g} / \mathrm{g} \text { soil })\end{array}$ & $\begin{array}{c}\text { Mineralizable } N \\
\text { ( } \mu \mathrm{g} \text { N/g soil/d) }\end{array}$ & $\underset{(\%)}{\mathrm{S}_{\mathrm{b}} \mathrm{OC}_{\mathrm{HW}} / \mathrm{TOC}}$ & $\underset{(\%)}{\mathrm{S}_{\mathrm{b}} \mathrm{ON}_{\mathrm{HW}} / \mathrm{TN}}$ \\
\hline Cedar & $7180.2 \mathrm{a}$ & $118.3 \mathrm{a}$ & $32.1 \mathrm{a}$ & $95.7 \mathrm{a}$ & $246.2 \mathrm{a}$ & $160.0 \mathrm{~b}$ & $3.28 \mathrm{a}$ & $0.70 \mathrm{a}$ \\
\hline Transition & $1838.3 \mathrm{~b}$ & $60.8 \mathrm{~b}$ & $37.4 \mathrm{a}$ & $52.6 \mathrm{a}$ & $150.8 \mathrm{~b}$ & $187.8 \mathrm{ab}$ & $2.45 \mathrm{~b}$ & $0.69 \mathrm{a}$ \\
\hline Bamboo & $2081.9 \mathrm{~b}$ & $74.6 \mathrm{~b}$ & $29.0 \mathrm{a}$ & $36.8 \mathrm{a}$ & $139.9 \mathrm{~b}$ & $218.4 \mathrm{a}$ & $2.58 \mathrm{~b}$ & $0.51 \mathrm{a}$ \\
\hline
\end{tabular}

Soil soluble organic carbon $\left(\mathrm{S}_{\mathrm{b}} \mathrm{OC}\right)$; ammonium $\left(\mathrm{NH}_{4}{ }^{+}\right)$; nitrate $\left(\mathrm{NO}_{3}{ }^{-}\right)$; soil soluble organic nitrogen $\left(\mathrm{S}_{\mathrm{b}} \mathrm{ON}\right)$; total dissolved nitrogen (TDN); total organic carbon (TOC); total nitrogen (TN). Values with the same letters are not significantly different at $p=0.05$ by Tukey's HSD test. 
The $\mathrm{S}_{\mathrm{b}} \mathrm{OC}_{\mathrm{HW}} / \mathrm{TOC}$ ratio was higher in the cedar than the transition and bamboo plantation soil, with no spatial variation found between the cedar and bamboo plantation soil in the $\mathrm{S}_{\mathrm{b}} \mathrm{OC}_{\mathrm{KCl}} / \mathrm{TOC}$ ratio. In addition, the $\mathrm{S}_{\mathrm{b}} \mathrm{ON}_{\mathrm{KCl}} / \mathrm{TN}$ ratio was higher in the bamboo than cedar plantation soil, with no spatial variation of $\mathrm{S}_{\mathrm{b}} \mathrm{ON}_{\mathrm{HW}} / \mathrm{TN}$ ratio found between the three vegetation types. In addition, the total mineralizable $\mathrm{N}$ content was similar among the three vegetation types.

Results from PCA showed that three principal components had eigenvalues $>1$ and explained $91.1 \%$ of the variance in the total data. The C-related parameters, $\mathrm{TOC}, \mathrm{S}_{\mathrm{b}} \mathrm{OC}_{\mathrm{KCl}}, \mathrm{S}_{\mathrm{b}} \mathrm{OC}_{\mathrm{HW}}, \mathrm{AHPI}-\mathrm{C}$, AHPII-C, and RP-C, and N-related parameters, $\mathrm{TN}$ and $\mathrm{NH}_{4}{ }^{+} \mathrm{HW}$, appeared to be the most important soil parameters affected by the bamboo invasion in PC- 1 and explained $64.6 \%$ of the variance. The $\mathrm{N}_{\text {mic }}$ and $\mathrm{NO}_{3}{ }^{-} \mathrm{HW}$ were the most important parameters in PC-2 and explained $16.5 \%$ of the variance. The total mineralizable $\mathrm{N}, \mathrm{NO}_{3}{ }^{-} \mathrm{HW}$ and $\mathrm{NO}_{3}{ }^{-} \mathrm{KCl}$ were the most important parameters in $\mathrm{PC}-3$ and explained $10.0 \%$ of the variance (Table 3 ).

The calculated SQI based on PCA results showed the cedar plantation with higher soil quality than the transition zone and bamboo plantation $(0.75 \pm 0.03$ vs. $0.38 \pm 0.04$ and $0.41 \pm 0.02)$ (Figure 1$)$.

Table 3. Eigenvalues and Eigenvectors of the first three principal components from principal component analysis and the selected parameters $\left(^{*}\right)$ for soil quality index calculation from the cedar plantation, transition zone, and bamboo plantation. ${ }^{\dagger}$ indicate values mainly contributed to the principal components (PCs).

\begin{tabular}{|c|c|c|c|}
\hline Principal Components & PC-1 & PC-2 & PC-3 \\
\hline Eigenvalue & 10.33 & 2.63 & 1.60 \\
\hline \multicolumn{4}{|l|}{ Eigenvactors: } \\
\hline $\mathrm{NH}_{4}^{+} \mathrm{KCl}$ & 0.252 & -0.122 & -0.194 \\
\hline $\mathrm{NO}_{3}{ }^{-} \mathrm{KCl}$ & 0.126 & 0.415 & $-0.477 *,+$ \\
\hline $\mathrm{S}_{\mathrm{b}} \mathrm{ON}_{\mathrm{KCl}}$ & 0.269 & 0.191 & 0.189 \\
\hline $\mathrm{S}_{\mathrm{b}} \mathrm{OC}_{\mathrm{KCl}}$ & $0.297^{\dagger}$ & 0.024 & 0.161 \\
\hline $\mathrm{NH}_{4}{ }^{+} \mathrm{HW}$ & $0.292^{+}$ & 0.030 & 0.030 \\
\hline $\mathrm{NO}_{3}{ }^{-} \mathrm{HW}$ & 0.048 & $0.476^{+}$ & $-0.466^{\dagger}$ \\
\hline $\mathrm{S}_{\mathrm{b}} \mathrm{ON}_{\mathrm{HW}}$ & 0.236 & 0.168 & 0.221 \\
\hline $\mathrm{S}_{\mathrm{b}} \mathrm{OC}_{\mathrm{HW}}$ & $0.300^{\dagger}$ & -0.062 & 0.124 \\
\hline Total mineralizable $\mathrm{N}$ & -0.084 & 0.415 & $0.474^{+}$ \\
\hline $\mathrm{C}_{\text {mic }}{ }^{1}$ & 0.241 & 0.227 & -0.125 \\
\hline $\mathrm{N}_{\text {mic }} 1$ & -0.115 & $0.491 *,+$ & 0.343 \\
\hline TOC & $0.308^{*},+$ & -0.025 & 0.027 \\
\hline $\mathrm{TN}$ & $0.307^{\dagger}$ & 0.034 & 0.038 \\
\hline AHPI-C ${ }^{2}$ & $0.291^{\dagger}$ & -0.022 & 0.039 \\
\hline AHPII-C ${ }^{2}$ & $0.286^{+}$ & -0.168 & 0.142 \\
\hline $\mathrm{RP}-\mathrm{C}^{2}$ & $0.306^{\dagger}$ & -0.145 & -0.091 \\
\hline
\end{tabular}

${ }^{1} \mathrm{C}_{\text {mic }}$ and $\mathrm{N}_{\text {mic }}$ data were from Chang and Chiu [16]. ${ }^{2}$ AHPI-C, AHPII-C and RP-C data were from Wang et al. [18].

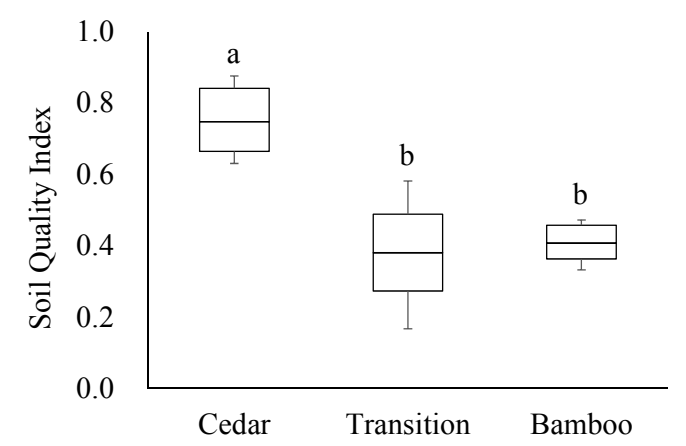

Figure 1. Soil quality index among the three vegetation types. Sites with the same letters are not significantly different at $p=0.05$ based on the Tukey's HSD comparison. 


\section{Discussion}

Bamboo tissue contains low lignin and has a relatively fast soil $\mathrm{C}$ cycle, whereas cedar tissue is strongly resistant to degradation and has a slow soil C cycle [28]. Previous research showed that bamboo decreased soil $\mathrm{C}$ and $\mathrm{N}$ content when it invaded a broad-leaved forest [29], perhaps because the bamboo litter contained more $\mathrm{O}$-alkyl-C, which can be more easily decomposed than that from coniferous forests [18]. Because the slow decomposing speed of cedar tissue helps accumulate TOC, high TOC further helps provide high $\mathrm{S}_{\mathrm{b}} \mathrm{OC}$ content in the cedar plantation soil. In addition, frequent human activities, such as bamboo shoot harvests, may speed up the removal of organic $\mathrm{C}$ from bamboo plantation soils [18]. These reasons may explain the low contents of TOC and $\mathrm{S}_{\mathrm{b}} \mathrm{OC}$ in the bamboo plantation soil.

$\mathrm{S}_{\mathrm{b}} \mathrm{OC}$ has been considered the most important indicator of soil quality [30] because increasing $\mathrm{S}_{\mathrm{b}} \mathrm{OC}$ content provides energy sources that can be easily utilized by the soil microbial community [31]. With the results of $C_{\text {mic }}$ as well as total phospholipid-derived fatty acids from Chang and Chiu [16] in a parallel study, $\mathrm{C}_{\mathrm{mic}}$ content was found the highest in cedar plantation soils. This finding could be evidence that increasing $\mathrm{S}_{\mathrm{b}} \mathrm{OC}$ content benefits microbial growth [32]. Moreover, $\mathrm{C}_{\text {mic }}$ content was positively correlated with $\mathrm{S}_{\mathrm{b}} \mathrm{OC}$ content and TOC in this study, so $\mathrm{S}_{\mathrm{b}} \mathrm{OC}$ content may be derived from the decomposition of soil TOC as a result of microbial activity [32].

The overall $\mathrm{S}_{\mathrm{b}} \mathrm{OC}_{\mathrm{KCl}}$ and $\mathrm{S}_{\mathrm{b}} \mathrm{OC}_{\mathrm{HW}}$ content that we found were positively correlated with TOC and $\mathrm{C}_{\mathrm{mic}}$ content (Figure 2). However, $\mathrm{S}_{\mathrm{b}} \mathrm{OC}_{\mathrm{HW}}$ content had steeper slopes when fitting to both TOC and $\mathrm{C}_{\text {mic }}$ content than $\mathrm{S}_{\mathrm{b}} \mathrm{OC}_{\mathrm{KCl}}$ content, so $\mathrm{S}_{\mathrm{b}} \mathrm{OC}_{\mathrm{HW}}$ content better reflected the labile portion of soil $\mathrm{C}$ that can be readily utilized by soil microbes than did $\mathrm{S}_{\mathrm{b}} \mathrm{OC}_{\mathrm{KCl}}$ content.
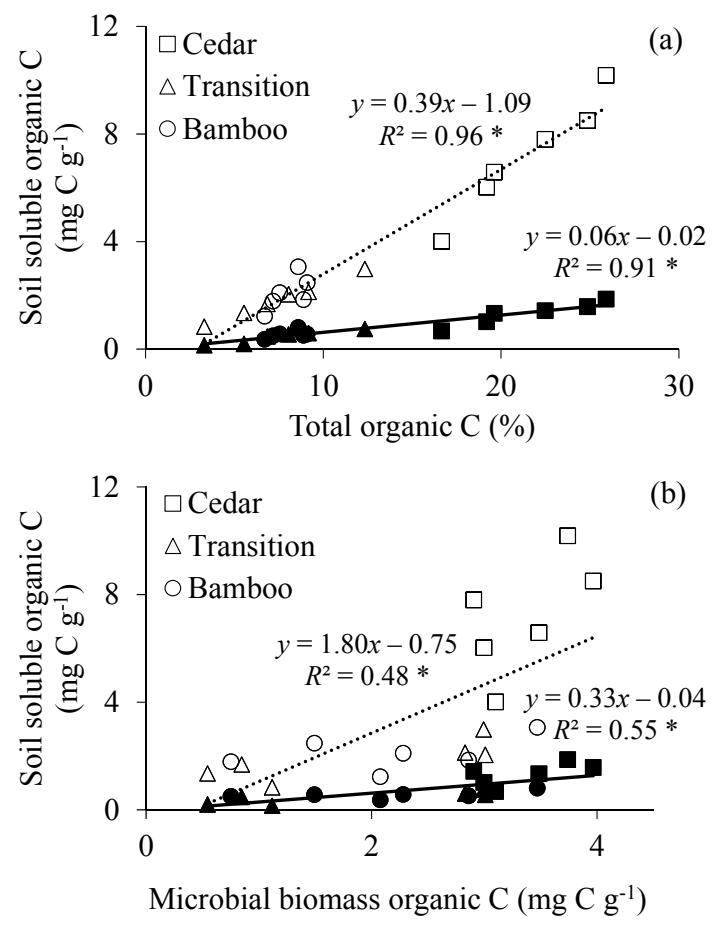

Figure 2. Correlation of the soil soluble organic carbon in $2 \mathrm{M} \mathrm{KCl}$ extracts (solid, $\mathrm{S}_{\mathrm{b}} \mathrm{OC}_{\mathrm{KCl}}$ ) and hot-water extracts (hollow, $\mathrm{S}_{\mathrm{b}} \mathrm{OC}_{\mathrm{HW}}$ ) with (a) soil TOC and (b) soil microbial biomass $\mathrm{C}\left(\mathrm{C}_{\text {mic }}\right)$ in moso bamboo plantation soil. $\mathrm{C}_{\text {mic }}$ data are from Chang and Chiu [16]. * indicates significant correlation between the two variables $(p<0.05)$.

Although Wang et al. [18] found that bamboo litter contained more easily decomposable substances and the ratio of hydrolysable $\mathrm{C}$ to TOC was higher in bamboo than cedar soil, a substantial amount of labile $\mathrm{C}$ still existed in cedar soil. The higher $\mathrm{S}_{\mathrm{b}} \mathrm{OC}_{\mathrm{HW}} / \mathrm{TOC}$ ratio in the cedar plantation 
than bamboo plantation confirmed that the $\mathrm{S}_{\mathrm{b}} \mathrm{OC}_{\mathrm{HW}}$ content was attributed to the increase in TOC pools through the cedar litter.

In addition, hot-water-extracted soil organic $C$ is typically considered readily metabolisable [33], whereas acid-hydrolysable $C$ is considered bioreactive $C$ that is not readily used by microbes [34]. The lower $\mathrm{S}_{b} \mathrm{OC}_{\mathrm{HW}}$ but higher acid-hydrolysable $\mathrm{C}$ content [18] in bamboo than cedar soil may imply that the labile $C$ pool in our bamboo soils was more likely to be bioreactive $C$ rather than readily metabolisable $\mathrm{C}$.

The $\mathrm{S}_{\mathrm{b}} \mathrm{OC}_{\mathrm{HW}} / \mathrm{TOC}$ ratio was higher in moso bamboo soils than other moso bamboo forest soils in the elevation gradient in Central Taiwan, particularly higher than those in low elevation plantation soils [20]. Because the bamboo plantation in the present study was established later (1970s) than those in low elevation plantation soils (1950s-1960s) [18,35], the higher $S_{b}$ OC content in the bamboo soils in this study than in other bamboo plantation sites at lower elevation may result from shorter cultivation history that removed less $C$ from the ecosystem.

$\mathrm{NH}_{4}{ }^{+}$and TDN contents were distinctly higher in cedar than bamboo plantation soil with both the hot-water and $\mathrm{KCl}$ extracts. However, only $\mathrm{S}_{\mathrm{b}} \mathrm{ON}_{\mathrm{KCl}}$ but not $\mathrm{S}_{\mathrm{b}} \mathrm{ON}_{\mathrm{HW}}$ content was highest in the cedar plantation soil. This finding could be due to $\mathrm{KCl}$ helping to extract clay particle-absorbed $\mathrm{S}_{\mathrm{b}} \mathrm{ON}$ [22]. In addition, the higher $\mathrm{SbON}_{\mathrm{KCl}} / \mathrm{TN}$ ratio in the bamboo plantation soils could be due to the lower TN content at the sites.

Overall, $\mathrm{S}_{\mathrm{b}} \mathrm{ON} \mathrm{NW}_{\mathrm{HW}}$ and $\mathrm{S}_{\mathrm{b}} \mathrm{ON}_{\mathrm{KCl}}$ contents were significantly correlated with $\mathrm{TN}$ but not $\mathrm{N}_{\text {mic }}$ content (Figure 3), so the $\mathrm{S}_{\mathrm{b}} \mathrm{ON}$ in soil may not directly affect microbial growth. In addition, the total mineralizable $\mathrm{N}$ has been previously considered an active fraction of soil organic $\mathrm{N}$. Thus, the high total mineralizable $\mathrm{N}$ content at the bamboo plantation in our study implies that the bamboo plantation contained high levels of active soil organic $\mathrm{N}$.
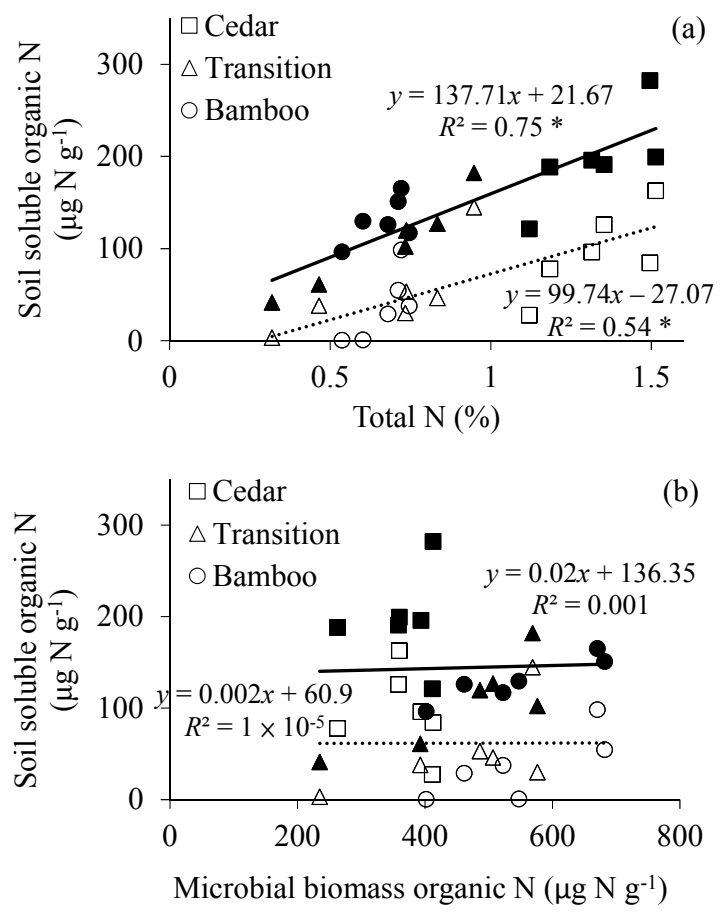

Figure 3. Correlation of the soil soluble organic nitrogen in $2 \mathrm{M} \mathrm{KCl}$ extracts (solid, $\mathrm{S}_{\mathrm{b}} \mathrm{ON}_{\mathrm{KCl}}$ ) and hot-water extracts (hollow, $\mathrm{S}_{\mathrm{b}} \mathrm{ON}_{\mathrm{HW}}$ ) with (a) soil total nitrogen and (b) soil microbial biomass $\mathrm{N}\left(\mathrm{N}_{\text {mic }}\right.$ ) in moso bamboo plantation soil. $\mathrm{N}_{\text {mic }}$ data were from Chang and Chiu [16]. * indicates significant correlation between the two variables $(p<0.05)$. 
As compared with our published parallel study in a badland soil (i.e., high clay and calcium carbonate content soil) systems, the changes in soil TOC composition with the bamboo plantation resulted in different outcomes as compared with the present study [8]. A possible reason for the different outcomes is the difference in net $C$ balance between the two ecosystems. Because soil TOC from a bamboo plantation is mostly in labile forms, it can improve badland soil quality with easily decomposable organic C. However, in the present study, the bamboo plantation was not able to reimburse recalcitrant organic $C$ loss from the soil that was previously grown with hardwood forests, which resulted in an overall organic $\mathrm{C}$ loss and degradation from the bamboo soils.

The results from PCA and SQI also provided supportive evidence for the soil property changes that bamboo invasion may introduce. PC-1 was composed of C-related parameters, which clearly indicates that soil TOC was the most sensitive soil property altered by the bamboo invasion. The reduction of TOC among the three vegetation types may further affect soil microbial growth, which resulted in $\mathrm{N}_{\text {mic }}$ as the most important parameter in $\mathrm{PC}-2 . \mathrm{NO}_{3}{ }^{-}$is one important nutrient in soil that supports plant and microbial growth, so $\mathrm{NO}_{3}{ }^{-}$was the most important parameter in PC-3.

Lu et al. [26] found SQI values of $<0.3,0.3-0.5$ and $>0.5$ for low-, intermediate- and high-quality soil. The calculated SQI among the three vegetation types clearly showed that the soil quality was degraded with the invasion of moso bamboo. The labile $\mathrm{C}$ and $\mathrm{N}$ provided by the bamboo plantation may still help the soil remain at intermediate quality.

\section{Conclusions}

The invasion of moso bamboo in a cedar forest sped up the $\mathrm{C}$ and $\mathrm{N}$ cycles in soil because of more $\mathrm{S}_{\mathrm{b}} \mathrm{OC}$ content in bamboo plantation soils, which can be easily decomposed by soil microbes. The short $\mathrm{C}$ and $\mathrm{N}$ cycles reduced the overall soil labile nutrients of bamboo plantation soils and further decreased the soil microbial biomass $\mathrm{C}$ content. From both $\mathrm{KCl}$ and hot-water extracts, the $\mathrm{S}_{\mathrm{b}} \mathrm{OC}$ and $\mathrm{NH}_{4}{ }^{+}$contents were significantly lower in bamboo than cedar plantation soils. Both $\mathrm{S}_{\mathrm{b}} \mathrm{OC}_{\mathrm{KCl}}$ and $\mathrm{S}_{\mathrm{b}} \mathrm{OC}_{\mathrm{HW}}$ contents were positively correlated with TOC and $\mathrm{C}_{\text {mic }}$ contents. Results from PCA further confirmed soil TOC, $\mathrm{N}_{\text {mic }}$ and $\mathrm{NO}_{3}{ }^{-}$as the three most sensitive factors altered by the bamboo invasion. Overall, the invasion of moso bamboo reduced the $\mathrm{C}$ and $\mathrm{N}$ pools in the bamboo soils and degraded the overall soil quality.

Acknowledgments: This work was funded by Ministry of Science and Technology (MOST-105-2313-B-001-002).

Author Contributions: C.Y.C. conceived and designed the experiments; Y.J.S. and C.Y.C. performed the experiments and analyzed the data; Y.J.S. wrote the original draft; C.Y.C. reviewed and edited the manuscript.

Conflicts of Interest: The authors declare no conflict of interest.

\section{References}

1. Tripathi, S.K.; Singh, K.P. Productivity and nutrient cycling in recently harvested and mature bamboo savannas in the dry tropics. J. Appl. Ecol. 1994, 31, 109-124. [CrossRef]

2. Zhuang, S.Y.; Ji, H.B.; Zhang, H.X.; Sun, B. Carbon storage estimation of moso bamboo (phyllostachys pubescens) forest stands in Fujian, China. Trop. Ecol. 2015, 56, 383-391.

3. Cheng, L.; Adhikari, S.; Wang, Z.H.; Ding, Y.L. Characterization of bamboo species at different ages and bio-oil production. J. Anal. Appl. Pyrolysis 2015, 116, 215-222. [CrossRef]

4. Lobovikov, M.; OPaudel, S.; MPiazze, M.; Ren, H.; We, J. World Bamboo Resources: A Thematic Study Prepared in the Framework of the Global Forest Resources Assessment 2005; Food and Agriculture Organization of the United Nations: Rome, Italy, 2007.

5. Hull, V.; Zhang, J.D.; Zhou, S.Q.; Huang, J.Y.; Vina, A.; Liu, W.; Tuanmu, M.N.; Li, R.G.; Liu, D.; Xu, W.H.; et al. Impact of livestock on giant pandas and their habitat. J. Nat. Conserv. 2014, 22, 256-264.

6. SijiMol, K.; Dev, S.A.; Sreekumar, V.B. A review of the ecological functions of reed bamboo, genus ochlandra in the western ghats of India: Implications for sustainable conservation. Trop. Conserv. Sci. 2016, 9, 389-407.

7. Xu, Y.; Wong, M.; Yang, J.; Ye, Z.; Jiang, P.; Zheng, S. Dynamics of carbon accumulation during the fast growth period of bamboo plant. Bot. Rev. 2011, 77, 287-295. 
8. Shiau, Y.J.; Wang, H.C.; Chen, T.H.; Jien, S.H.; Tian, G.L.; Chiu, C.Y. Improvement in the biochemical and chemical properties of badland soils by thorny bamboo. Sci. Rep. 2017, 7. [CrossRef]

9. Shinohara, Y.; Otsuki, K. Comparisons of soil-water content between a moso bamboo (phyllostachys pubescens) forest and an evergreen broadleaved forest in western Japan. Plant Species Biol. 2015, 30, 96-103.

10. Yang, L.; Zhang, F.; Gao, Q.; Mao, R.; Liu, X. Impact of land-use types on soil nitrogen net mineralization in the sandstorm and water source area of Beijing, China. Catena 2010, 82, 15-22. [CrossRef]

11. Li, R.; Werger, M.J.A.; During, H.J.; Zhong, Z.C. Carbon and nutrient dynamics in relation to growth rhythm in the giant bamboo phyllostachys pubescens. Plant Soil 1998, 201, 113-123.

12. Chou, C.H.; Yang, C.M. Allelopathic research of subtropical vegetaions in Taiwan II. Comparative exclusion of understory by Phyllostachys edulis and Cryptomeria japonica. J. Chem. Ecol. 1982, 8, 1489-1507. [CrossRef] [PubMed]

13. Bai, S.; Zhou, G.; Wang, Y.; Liang, Q.; Chen, J.; Cheng, Y.; Shen, R. Plant species diversity and dynamics in forests invaded by moso bamboo (phyllostachys edulis) in Tianmu Mountain nature reserve. Biodivers. Sci. 2013, 21, 288-295.

14. Zhang, C.; Xie, G.; Fan, S.; Zhen, L. Variation in vegetation structure and soil properties, and the relation between understory plants and environmental variables under different phyllostachys pubescens forests in southeastern China. Environ. Manag. 2010, 45, 779-792. [CrossRef] [PubMed]

15. Umemura, M.; Takenaka, C. Retranslocation and localization of nutrient elements in various organs of moso bamboo (phyllostachys pubescens). Sci. Total Environ. 2014, 493, 845-853. [CrossRef] [PubMed]

16. Chang, E.-H.; Chiu, C.-Y. Changes in soil microbial community structure and activity in a cedar plantation invaded by moso bamboo. Appl. Soil Ecol. 2015, 91, 1-7. [CrossRef]

17. Lin, Y.-T.; Tang, S.-L.; Pai, C.-W.; Whitman, W.B.; Coleman, D.C.; Chiu, C.-Y. Changes in the soil bacterial communities in a cedar plantation invaded by moso bamboo. Microb. Ecol. 2013, 67, 421-429. [CrossRef] [PubMed]

18. Wang, H.-C.; Tian, G.; Chiu, C.-Y. Invasion of moso bamboo into a Japanese cedar plantation affects the chemical composition and humification of soil organic matter. Sci. Rep. 2016, 6, 32211. [CrossRef] [PubMed]

19. Ghani, A.; Dexter, M.; Perrott, K.W. Hot-water extractable carbon in soils: A sensitive measurement for determining impacts of fertilisation, grazing and cultivation. Soil Biol. Biochem. 2003, 35, 1231-1243. [CrossRef]

20. Huang, C.-Y.; Jien, S.-H.; Chen, T.-H.; Tian, G.; Chiu, C.-Y. Soluble organic c and $\mathrm{n}$ and their relationships with soil organic $\mathrm{c}$ and $\mathrm{n}$ and microbial characteristics in moso bamboo (phyllostachys edulis) plantations along an elevation gradient in central Taiwan. J. Soil Sedim. 2014, 14, 1061-1070. [CrossRef]

21. Strosser, E. Methods for determination of labile soil organic matter: An overview. J. Agrobiol. 2010, 27, 49-60. [CrossRef]

22. Ros, G.H.; Hoffland, E.; Temminghoff, E.J.M. Dynamics of dissolved and extractable organic nitrogen upon soil amendment with crop residues. Soil Biol. Biochem. 2010, 42, 2094-2101. [CrossRef]

23. Soil Survey Staff. Keys to Soil Taxonomy, USDA-NRCS Agricultural Handbook No. 436, 11th ed.; U.S. Government Printing Office: Washington, DC, USA, 2010.

24. Sollins, P.; Glassman, C.; Paul, E.A.; Swanston, C.; Lajtha, K.; Heil, J.W.; Elliott, E.T. Soil carbon and nitrogen: Pools and fractions. In Standard Soil Methods for Long-Term Ecological Research; Robertson, G.P., Coleman, D.C., Bledsoe, C.S., Sollins, P., Eds.; Oxford University Press: New York, NY, USA, 1999; pp. 89-105.

25. Waring, S.A.; Bremner, J.M. Effect of soil mesh-size on estimation of mineralizable nitrogen in soils. Nature 1964, 202, 1141. [CrossRef]

26. Lu, X.; Toda, H.; Ding, F.; Fang, S.; Yang, W.; Xu, H. Effect of vegetation types on chemical and biological properties of soils of karst ecosystems. Eur. J. Soil Biol. 2014, 61, 49-57. [CrossRef]

27. Mukherjee, A.; Lal, R. Comparison of soil quality index using three methods. PLoS ONE 2014, 9, e105981. [CrossRef] [PubMed]

28. Nakane, K. Soil carbon cycling in a Japanese cedar (cryptomeria-japonica) plantation. For. Ecol. Manag. 1995, 72, 185-197. [CrossRef]

29. Fukushima, K.; Usui, N.; Ogawa, R.; Tokuchi, N. Impacts of moso bamboo (phyllostachys pubescens) invasion on dry matter and carbon and nitrogen stocks in a broad-leaved secondary forest located in kyoto, western Japan. Plant Species Biol. 2015, 30, 81-95. [CrossRef] 
30. Reeves, D.W. The role of soil organic matter in maintaining soil quality in continuous cropping systems. Soil Tillage Res. 1997, 43, 131-167. [CrossRef]

31. Saleem, M. Microbiome Community Ecology: Fundamentals and Applications; Springer International Publishing: New York, NY, USA, 2015.

32. Saleem, M.; Fetzer, I.; Harms, H.; Chatzinotas, A. Trophic complexity in aqueous systems: Bacterial species richness and protistan predation regulate dissolved organic carbon and dissolved total nitrogen removal. Proc. R. Soc. B Biol. Sci. 2016, 283, 20152724. [CrossRef] [PubMed]

33. Nishiyama, M.; Sumikawa, Y.; Guan, G.; Marumoto, T. Relationship between microbial biomass and extractable organic carbon content in volcanic and non-volcanic ash soil. Appl. Soil Ecol. 2001, 17, 183-187. [CrossRef]

34. Xu, J.M.; Cheng, H.H.; Koskinen, W.C.; Molina, J.A.E. Characterization of potentially bioreactive soil organic carbon and nitrogen by acid hydrolysis. Nutr. Cycl. Agroecosyst. 1997, 49, 267-271. [CrossRef]

35. Wang, H.C.; Chou, C.Y.; Chiou, C.R.; Tian, G.L.; Chiu, C.Y. Humic acid composition and characteristics of soil organic matter in relation to the elevation gradient of moso bamboo plantations. PLoS ONE 2016, 11, e0162193. [CrossRef] [PubMed]

(C) 2017 by the authors. Licensee MDPI, Basel, Switzerland. This article is an open access article distributed under the terms and conditions of the Creative Commons Attribution (CC BY) license (http:/ / creativecommons.org/licenses/by/4.0/). 